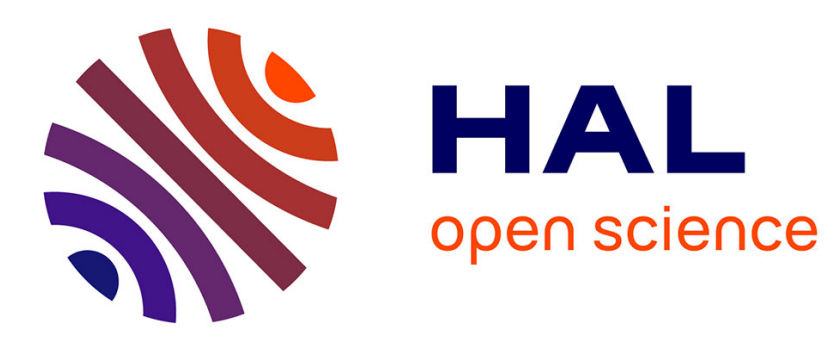

\title{
First Evidence of a HIV-1 M/O Recombinant Form Circulating Outside Cameroon
}

M Leoz, A Vessiere, V Brodard, C. Strady, A Depatureaux, V Lemee, J C Plantier

\section{- To cite this version:}

M Leoz, A Vessiere, V Brodard, C. Strady, A Depatureaux, et al.. First Evidence of a HIV-1 M/O Recombinant Form Circulating Outside Cameroon. CROI, Feb 2009, Montreal, Canada. hal-02264822

HAL Id: hal-02264822

https://hal-normandie-univ.archives-ouvertes.fr/hal-02264822

Submitted on 7 Aug 2019

HAL is a multi-disciplinary open access archive for the deposit and dissemination of scientific research documents, whether they are published or not. The documents may come from teaching and research institutions in France or abroad, or from public or private research centers.
L'archive ouverte pluridisciplinaire HAL, est destinée au dépôt et à la diffusion de documents scientifiques de niveau recherche, publiés ou non, émanant des établissements d'enseignement et de recherche français ou étrangers, des laboratoires publics ou privés. 


\section{Pôle Biologie} Unité de Virologie CHu de Rouen

Equipe d'accueil EA2656 Faculté de Médecine - Pharmacie Université de Rouen

\section{First Evidence of a HIV-1 M/O Recombinant Form Circulating Outside Cameroon}

\section{Leoz 1 , A Vessiere 2 , V Brodard ${ }^{3}$, C Strady ${ }^{3}$, A. Depatureaux ${ }^{1}$, V Lemee ${ }^{1}$, JC Plantier ${ }^{1}$}

${ }^{1}$ CHU Charles Nicolle, Rouen, France, ${ }^{2}$ Centre Pasteur du Cameroun, Yaoundé, Cameroun, ${ }^{3}$ CHU Robert Debré, Reims, France

\section{INTRODUCTION:}

HIV-O infection is endemic in Cameroon. Among these patients HIV-O positive ( $=1 \%$ of all HIV infections), seroprevalence studies showed at least $10 \%$ of HIV-M/HIV-O dual infections, but only three O/M recombinant forms have been previously described $[1,2,3]$.

In France, 119 patients have been yet identified with HIV-O infection, most of them originating from Cameroon. The suspicion of HIV-O infection often comes on the occasion of diagnosis difficulties or virological-clinical discordances due to their high genetic divergence compared to HIV-M, which can lead to poor or total lack of detection by certain commercial tests.

\section{PATIENTS AND METHODS:}

A 25years old Cameroonian woman (RBF209) living in France since 2000 had consulted at the Universitary Hospital of Reims (eastern France) in May 2008. Her biological and virological analyses indicated (tab.1): $-\mathrm{CD} 4=6 / \mathrm{mm}^{3}$

viral load $=$ undetectable $($ Roche Cobas Taqman

- viral load $=6.10^{4} \mathrm{cop} / \mathrm{ml}$ (Abbott Realtime)

Complementary analyses were performed using :

- in-house HIV-O specific viral loads, targeting the LTR and integrase regions

-serotyping assay using peptides that mimic the Immuno-Dominant Region (IDR) of the gp41 and the V3 loop of the gp120 specific to HIV-1 groups $\mathrm{M}, \mathrm{N}$ and $\mathrm{O}$ and HIV-2

HIV-O or M group-specific PCR in the Protease, Reverse Transcriptase (RT), Integrase and $\mathrm{Gp} 41$ regions

near full-lengh genome characterization from viral RNA and intracellular DNA, using non specific XL-RTPCR and XL-PCR, and sequencing with a set of 37 primers.

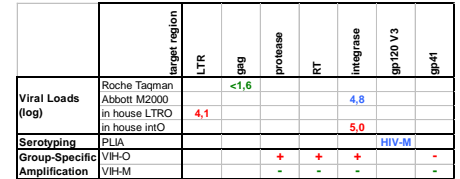

Table 1: Viral loads, serotyping and group-specific amplifications results. Group $O$ specific results are indicated in red, group $M$ specific in green, and non specific in blue.

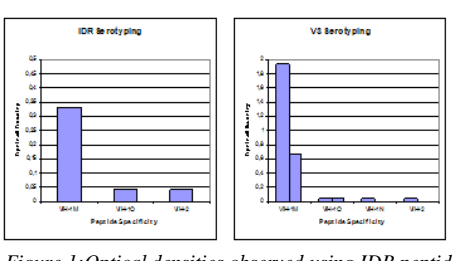
Figure 1: Optical densities observed using IDR peptides
(a) or V3 peptides (b) of various HIV types and groups

\section{RESULTS:}

The viral loads results were firstly in favour of a group $\mathrm{O}$ infection. The HIV-M specific Roche Cobas Taqman test was undetectable while the HIV-O specific methods were positive as the non specific Abbott M2000 (tab.1). However, serotyping clearly indicated a specific group M reactivity (figl).

Group specific amplifications were positive only for HIV-O in the $\mathrm{pol}$ gene, and surprisingly no group-specific amplification was positive in the gp41 region (tab.1).

The near full length sequencing of the circulating viral RNA revealed a O-M-O recombinant form (fig.2) with a breakpoint in the gp41 region, explaining the negative results with groupspecific primers. Another breakpoint was located on the first codon of $v p r$, where two of the three previously described $\mathrm{M} / \mathrm{O}$ recombinants already shown a group switch.

Phylogenetic analyses indicated that RBF209 was not linked to the other $\mathrm{M} / \mathrm{O}$ recombinants (fig.3).

The absence of HIV-O specific antibodies ( $f i g .1$ ) together with the negativity of group M specific PCR in the pol gene and no amplication of $\mathrm{M}$ or $\mathrm{O}$ in the gp41, suggest that this young patient does not carry the parental HIV-O and HIV-M strains.
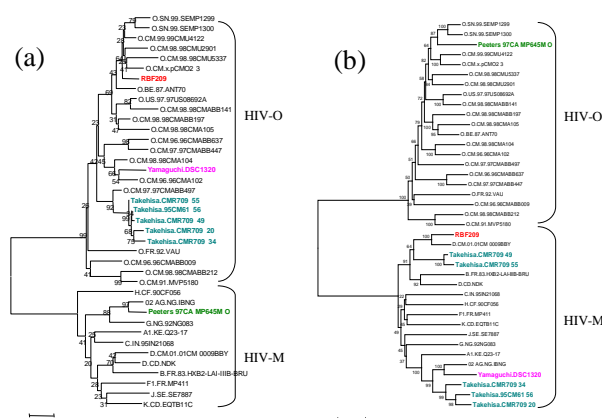

Figure 3: Phylogenetic analysis of the integrase region (a) and the vpr to gp 120 region (b) of the RBF209 isolate together with the three previously described $M / O$ recombinant forms. Method: NeighborJoining (1000 bootstraps tests), Distances Calculation: Kimura-2Parameters model

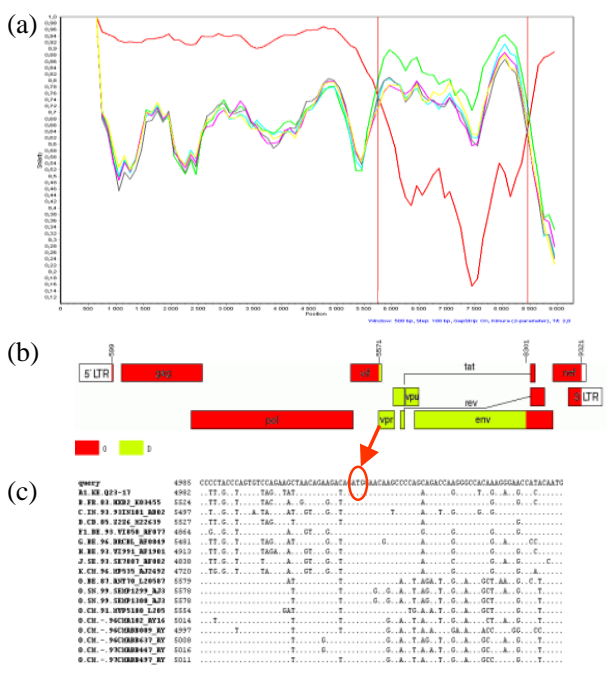

Figure 2: Characterization of the near full lenght $O-M$-O recombinant form. (a) Similarity plot indicating a HIV-O / HIV-M subtype D / HIV $O$ structure; (b) mapping the breakpoints on HIV-1 genome; (c) evidence of O/M recombination on the firs codon of vpr

\section{CONCLUSION:}

This fourth intergroup M/O recombinant form is the first described outside Cameroon.

Unlike the previously described cases witch emerged during a co-infection, this could be the first direct transmission by a $\mathrm{M} / \mathrm{O}$ recombinant form ever described, emphasizing the dynamic and a possible spread of such strains.

This kind of genome structure has consequences for the follow up and treatment of the patient, as there are HIV-O related mutations in the pol-encoding protease, RT and integrase, but targets of the entry inhibitors are HIV-M. With three intergroup recombinants switching in the $v p r$ gene and the fourth at the end of the integrase, the hypothesis of a hotspot of intergroup recombination in $v p r$ or around the accessory genes region has to be explored.

\section{REFERENCES:}

[1] Takehisa et al; Human Immunodeficiency Virus Type 1 Intergroup (M/O) Recombination in Cameroon. J. Virol 1999; 73:6810-6820 